\title{
UČENJE PLESA, UČENJE S PLESOM
}

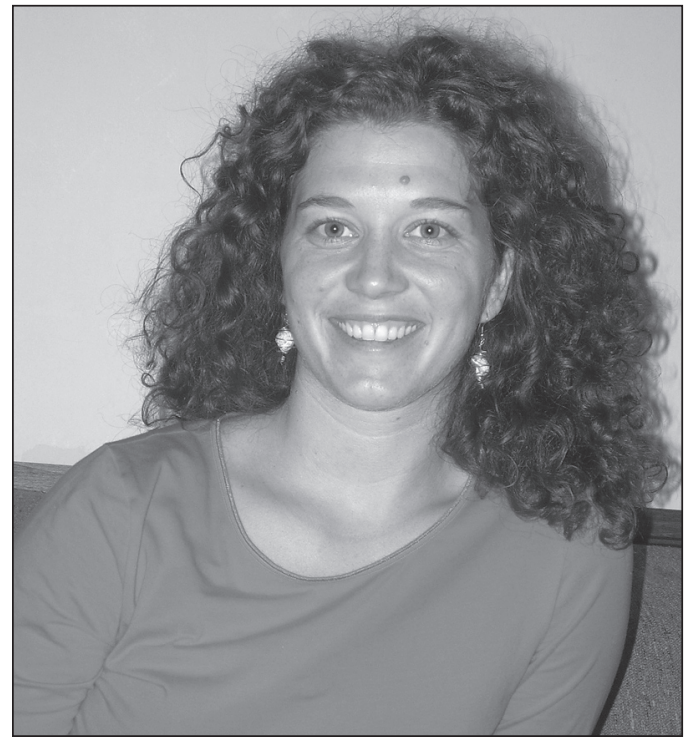

M

onika Požek je popotnica, plesalka, umetnica, ki se nenehno uči in s svojimi ustvarjalnimi potmi spodbuja okolje, da se uči. S svojimi izbirami stopi korak čez ustaljena pričakovanja in tako prisili okolje, da pogleda na življenje tudi drugače. Diplomirala je na Filozofski fakulteti v Ljubljani leta 2003. Formalni študij je ni navdušil. Njeno »pravo« učenje se dogaja na potovanjih in s plesom. Z njo smo se pogovarjali o njenih popotnih in plesnih doživetjih in o transgresivnem učenju. Ko razmišljamo o izobraževanju odraslih, je to pogosto povezano predvsem z učenjem za delo in s tako imenovanim prodanim časom. Poznane so tudi povezave $\mathrm{z}$ dejavnim vključevanjem v tokove odločanja, opismenjevanja, socialnega in gospodarskega razvoja. Manj pogosto opazujemo izobraževanje, ki se dogaja v dru- gih prostorih življenja - v povezavi s telesom, z zdravjem, ljubeznijo, etičnostjo ... Sodobne raziskave učenja $\mathrm{v}$ odraslosti se ukvarjajo $\mathrm{z}$ novimi koncepti, med katerimi so somatsko učenje, duhovno učenje, narativno učenje, biografsko učenje, priložnostno učenje, samoregulacijsko učenje, kar omogoča tudi opazovanje drugačnih poti učenja. Učenje plesa je ena od dejavnosti, ki vključuje človeka kot celovito bitje, deluje lahko terapevtsko in vzgojno, kar prikazuje tudi sogovornica v svoji pripovedi, in ne pomeni le gibanja $\mathrm{z}$ nogami.

Zdaj je v Argentini, kjer ljudje veliko plešejo, a ne toliko tango, kot bi morda pričakovali. Tango veliko plešejo turisti. Pravi, da še nikoli ni videla toliko plešočih Japoncev. Med domačini so zelo popularni njihovi folklorni plesi s svojo barvitostjo in energijo.

\section{Kdaj si začela plesati?}

Že v osnovni šoli sem bila vpisana v plesno šolo, kjer sem začela splošni plesni tečaj, poskusila akrobatski rock'n' roll in se v najstniških zaljubila v hip-hop ter s skupino trenirala, nastopala in tekmovala osem let.

\section{Ples si kasneje pustila ... in se vrnila.}

Zelo malo ljudi razume hip-hop kot ples, za večino je to zabava in telovadba z ulice, za katero ne potrebuješ treninga. Večina plesalcev hip-hopa po nekaj letih resnih treningov preneha, ker je težko uskladiti službo, treninge in denar. Nisem bila izjema. Ples mi je veliko pomenil, vendar sem želela početi veliko stvari. Med študijem sem začela delati in postala zelo aktivna $v$ mednarodni študentski organizaciji ter začela potovati na mednarodne seminar- 
je in tečaje. Potrebovala sem nadomestilo za opuščene treninge in začela sem razmišljati o drugih plesih. Zanimal me je flamenco, swing, želela sem nekaj novega. Moje prvo pravo potovanje je bila Brazilija in odločitev za to deželo je bila preprosta: samba in sonce. Ob vrnitvi sem iskala nekaj, kar bi me približalo ritmom Brazilije in najbližji takrat je bil flamenco, saj salsa in samba še nista prišli do Slovenije. Ples je postal moja dodatna dejavnost.

Kako si začela povezovati ples in poučevanje? Dokončan študij andragogike mi ni dal praktičnega znanja in po štirih letih študija nisem hotela delati na klasičnem področju izobraževanja odraslih. Med in po študiju sem veliko potovala, organizirala mednarodne konference ter delavnice za tuje študente in spoznavala veliko dinamičnih ter aktivnih ljudi. Splet želja, interesov in radovednosti me je ustavil v Španiji, kjer sem želela nadaljevati s flamencom. Status priseljenke me je prisilil k realnemu življenju: učenju španščine in sprejeti katero koli delo. Čez čas sem dobila možnost poučevanja angleščine na bolj dinamičen način, prek plesa, gledališča. To delo je bilo veliko presenečenje zame, saj sem začela uživati v poučevanju, ker sem lahko svoje delo povezala s plesom.

\section{Trenutno živiš v Buenosu Airesu. Zakaj ravno Argentina?}

Poučevanje prek plesa je bilo novo odkritje zame in želela sem več. Spomladi 2008 sem bila sprejeta na seminar v Nemčijo, namenjen učiteljem, ki učijo prek plesa in odrskih umetnosti. To je pripomoglo k odločitvi, da bi delala na tem področju. V Evropi ni veliko držav, ki ponujajo program plesne terapije, in cena je neprimerno višja kot tu. Odločitev za Argentino je bila lahka. Od tu izhaja nekaj zelo pomembnih profesorjev plesne terapije, denimo Karin Fleischer, Maria Fux. Veliko je gostujočih terapevtev iz ZDA. Na splošno je velika ponudba in večino tehnik lahko vidiš, doživiš v praksi. Buenos Aires na tem področju po- nuja veliko plesa, novih metod poučevanja in inovativnosti. Programi in tečaji plesne terapije so zelo raznoliki, profesionalni in predvsem finančno dostopni.

\section{Kako si našla šole in tečaje?}

Večino programov se najde na internetu, na tečajih spoznaš ljudi in dobiš še več informacij. Tu so učitelji, terapevti, psihologi izjemno dojemljivi za nove tehnike učenja. Plesna terapija je $\mathrm{v}$ razcvetu in ogromno je šol, ki ponujajo različne metode: eutania, biodanza, physical theatre. Tečaji so vedno polni, za seminarje čez konec tedna, ki so namenjeni bodočim terapevtom, pa se je treba prijaviti tudi nekaj mesecev vnaprej. Izobražujem se na sedežu Organizacije za plesno terapijo Argentina. Obiskujem tudi druge tečaje: authentic movement in tečaj plesne integracije, ki vključuje ljudi s posebnimi potrebami (la gente especi$a l$ ), ter plesno terapijo po metodi Marie Fux.

\section{Kako poteka učenje? Kaj te najbolj spod- buja?}

Povezujem različne tečaje in metode. Ne želim se strogo usmeriti le v eno metodo, saj te različne tehnike in izkušnje drugih profesorjev vedno bogatijo. Tečaji so praktično naravnani. Zelo malo je teorije. To pridobim iz knjig. Organizacija plesne terapije Argentina (Asociación de Danzaterapia Argentina) pa ponuja vsak teden delavnico, kjer se predava teorija, predvaja dokumentarne filme o začetkih plesne terapije v ZDA in Evropi. Okolje je zelo spodbujajoče in na tečajih spoznam veliko strokovnjakov, terapevtov, psihologov, ki delajo v bolnišnicah, imajo svoje skupine plesne terapije in te vedno povabijo $\mathrm{k}$ sodelovanju. Vidim možnosti dela in vidim tudi spremembe na ljudeh, ki obiskujejo terapijo dlje časa.

\section{Občutiš ples kot trening telesa ali tudi tre- ning duha?}

Ples je trening duha in telesa. Ples je nekaj naravnega in prirojenega vsakemu. Posameznik, 
ki trdi, da ne zna plesati, je pozabil svoje primarno gibanje. Mislim, da vsaka oseba lahko pleše. Ples je zasnovan v vsakem človeku kot nagon, z vzgojo in kulturo se lahko razvije ali zamre, vendar ga telo ne pozabi. Ples spodbuja naše gibanje in je v veliki meri trening duha, kjer se prek gibanja izražajo naše sposobnosti, čustva in razmišljanje. Problem je, ker večina ljudi ob plesu pomisli na tehniko, na korake in ne na gibanje, ki je pogosto spontano. Ples sprošča. Ker danes nimamo več časa v vsakodnevnem življenju, smo ga strpali v nočne klube in v plesne šole.

\section{Kaj boš počela z znanjem, pridobljenim na} teh tečajih?

Uživam v poučevanju starejše populacije in plesni integraciji - to je plesu z invalidi, to mi pomeni pravi izziv. Nisem prepričana, ali se bom vrnila v Slovenijo ali pa bom začela delo kje drugje v Evropi. Gotovo bom nadaljevala v tej smeri in povezovala ples s poučevanjem. Veliko možnosti vidim zunaj zdravstvenih institucij.

\section{Ples kot kreacija in rekreacija, ples kot vzgo-} ja: kaj to pomeni za razvijanje identitete?

Ples kot obliko gibanja in druženja je sodobni, razviti svet spremenil v šport in tekmovalnost. Plesa se ne povezuje $z$ osebnostno rastjo, temveč z »kdo zna bolje«. Primitivni ples nima tehnične podlage, ker temelji na gibanju, na ritmih in na ritualih. Ko si kreativen, rekreiraš svoje telo in svoje možgane.

Hip-hop in break dance sta se razvila na ulicah ZDA kot kulturno gibanje med mladimi v getu. Začelo se je kot način druženja in odgovor na družbo, ki izloča priseljence. V zadnjih letih se je pojavil fenomen rave party, ki se kaže kot sprostitev in protest proti vsakdanjim stresom in pritiskom. Vsi ti plesi niso plesna terapija, vendar imajo učinek »avtoterapije«, samovzgoje, razvoja identitete. Odrasli so pozabili plesati iz zabave in se sprostijo le, ko že obvladajo tehniko nekega plesa. Izginile so oblike primitivnih plesov, ples obstaja kot oblika za- bave za mlade. Odrasli imajo vedno v podzavesti vprašanje: »Kako me vidi drugi, ko plešem? « Pri plesu pa je pomembna spontanost, sproščenost. Ko plešeš, si v dialogu s samim seboj, plešeta skupaj tvoje telo in tvoj razum.

Kaj meniš o plesu kot dvojini: kaj pomeni prilagajanje soplesalcu? Kako lahko razviješ dialog s soplesalcem?

Soplesalec spremeni potek dialoga in spodbudi novo komunikacijo. Ni toliko odvisno od vrste plesa kot od obeh plesalcev. Lastni ego mora plesalec voditi v sodelovanje. Ne čutiš samo svojega telesa, temveč tudi telo in bližino soplesalca, kar lahko predstavlja konflikt, saj je vse odvisno od različnih percepcij. Tvoj osebni prostor je lahko veliko večji kot moj, vendar tanga ne moreš plesati meter stran od plesalca. Kot sem že omenila, je ples vedno neke vrsta avtoterapija, samovzgoja: učenje prilagajanja, poslušanja, čutenja in izpostavljanja svojega jaza drugemu. Ples kot dvojina sta vedno dva ega, ki se skušata zliti v eno, ne da bi pri tem izgubila svojo identiteto in različnost.

\section{Omenila si že plesno terapijo, ki je v vzpo- nu. Kaj sama meniš o tem?}

Ples kot terapija ni nekaj novega, vendar zelo pozno prihaja v Evropo. V Argentini in ZDA je že kar dolga tradicija plesne terapije in je vključena $\mathrm{v}$ programe veliko bolnišnic, psihiatričnih ustanov ter rehabilitacijskih centrov. Novost je, da se plesno terapijo čedalje bolj uporablja zunaj zdravstvenih institucij, v šolah in plesnih centrih. Gre za spontano gibanje, brez naučenih korakov, gre za povezovanje telesa, razuma in duše. Delo s plesno terapijo ima pozitivne učinke pri koncentraciji, večji gibljivosti, deblokaciji zavrtih čustev, dvigu samopodobe. Velik uspeh dosega pri bolnikih s parkinsonovo boleznijo, downovim sindromom, anoreksičnih mladostnikih. Za zdaj še nimamo samostojnega študija za plesno vzgojo. Delovanje v sklopu plesne terapije ali vzgoje je nadgradnja drugega poklica in pra- 
kse. Vsi plesni terapevti so izobraženi plesalci, psihologi, pedagogi, učitelji, ki v svoje delo vpletajo ples in gibanje.

Ples kot sproščanje in samospoznavanje: ali ples doživljaš kot skrito govorico duše? Mar med plesom pride na dan vse pozabljeno?

Ples vedno povežemo z glasbo. Ples kot sprostitev pomeni spontanost, ko se gibaš, kakor želiš. Prav tako je užitek tudi tedaj, ko že dovolj obvladaš določen ples in ne misliš samo na korake ali kako boš pohodil partnerja, ampak začneš doživljati ples-in-glasbo. Moderni plesi temeljijo na izražanju čustev in notranjega doživljanja plesalca, dihanju, meditaciji, ravnotežju (tehnika graham, pilates, improvizacijski ples, butoh...), zato jih nekateri označujejo kot terapevtski plesi. Jaz doživljam vse plese kot »terapijo«, kot dejavnost, ki te sprosti, nasmeje, zbliža s soplesalci. Pri bolj meditativnih plesih v povezavi z glasbo večkrat privrejo na dan čustva in pozabljeno. Pri družabnih plesih je ravno obrnjeno - pozabiš na vse. V plesu si dovoliš več kot v vsakdanjem življenju, zmanjšaš osebni prostor in se bolj dotakneš sebe v globini in drugih. Plesna terapija zelo vpliva in pomaga pri spoznavanju samega sebe, saj moraš precej delati s samim seboj.

Poleg plesa je za tvoje učenje pomembno tudi potovanje. Po diplomi si šla na pot ... Je bila Indija prvo daljše potovanje?

Po diplomi sem šla v Indijo, na potovanje za šest mesecev. Potovanje sem hotela izkoristiti tudi za učenje indijskih plesov. Na vlaku sem spoznala dekle iz Argentine, ki mi je povedala za učiteljico tradicionalnega plesa iz Kerale. $\mathrm{V}$ mali vasi na jugu Indije sem ostala mesec dni, se učila klasičnega indijskega plesa Mohiniyattam, filozofije ter zgodovine indijskih plesov. Predvsem sem se naučila spoštovanja: pristop učitelja $\mathrm{k}$ učencu ima pri plesu drugačen pomen. Učitelj je avtoriteta in hkrati tvoj vzor, ki pa ga lahko presežeš. Videla sem neverjetno predanost plesalcev, ki so bili na odru tudi po osem ali deset ur in prek plesa pripovedovali legende indijskih bogov.

Kako si doživela deželo in kako izbiraš dežele, kamor boš odšla?

Indija je popolnoma drug svet, drugačni nazori in drugačne vrednote. Čeprav je velik kaos, zmeda na cesti, hrup, veliko ljudi, je še vedno občutiti nekaj, česar v Evropi ne najdeš: odsotnost stresa. Jaz osebno ne maram prevelike organiziranosti in reda, uživam v uličnem življenju, kaosu, nepravilnostih, zato se je zelo lahko odločiti, kam naprej. Moja radovednost se ponavadi poveže s plesom, literaturo in tudi klimo države. Obožujem sonce, vročino in barve. Nisem še odkrila Afrike, ki je pravi plesni zaklad, in tudi še kar precej Azije me čaka.

\section{Katere dežele so se ti najbolj vtisnile kot} učne poti?

Zadnje daljše potovanje je bila enomesečna Rusija, ki je še vedno zelo avtentična in surova s svojim podnebjem. Ni veliko turizma in ljudje še nimajo $\mathrm{v}$ zavesti, da se moraš do turistov obnašati drugače: prijazno in z nasmeškom. To mi je bilo neznansko všeč, čeprav je bilo na trenutke težko potovati. Bolj kot arhitektura, kulinarika ter pokrajina name vplivajo domačini in njihov način življenja. Na poti se vedno učim, in medtem ko se rušijo moji stereotipi, vedno znova naletim na stereotipnost, ki jo imajo v drugih deželah. V Španiji sem bila »uboga Rusinja«, v Rusiji so me trepljali po hrbtu, češ da smo dobri bratje, v ZDA so me vprašali, ali je mogoče $v$ Sloveniji naročiti pico na dom, v Argentini mi je gospa zatrdila, da je bila pet let nazaj v Sloveniji, v mestu Trst, in podobno.

Vedno znova me sprašujejo, če ne mislim nehati potovati in se ustaliti, ker sem ženska in samska. A v tem ne vidim razloga, da bi prenehala.

Vse, kar je drugačno, predstavlja nevarnost. Dokler to ljudi spravi v smeh, je odlično. Vendar je večino ljudi strah, strah pred drugačno- 
stjo, strah pred novostmi, strah pred odločitvami. Ne bom pozabila potovanja po Indiji, ko so me dekleta in ženske ves čas spraševale, zakaj ne počešem svojih kodrastih las in si jih ne zravnam, saj takšna, kot sem, res ne bom dobila moža.

\section{Kako so te potovanja spreminjala?}

Dolga potovanja in življenje v tujini te spremenijo dosti bolj intenzivno in hitro kot domači kraj. Ko sem se vrnila domov, se mi je zdelo, da so se preostali nekam čudno spremenili, ali bolje: vprašaš se, zakaj se ni nič spremenilo. Kot oseba in ženska sem odrasla v tujini, zato je včasih težka vrnitev. Zdi se, da te ne spoznajo več in želijo enako osebo, kot je bila pred odhodom v tujino. Potovanja spreminjajo moj NE $v$ glavi in spreminjajo strahove $\mathrm{v}$ zanimive situacije. Spremenila me je družina na vzhodu Indije, ki me je vprašala »Koliko krav potrebuje družina v Sloveniji, da lahko preživi?«; spremenil me je starejši gospod, ko sem stopila na Portugalsko in mi je rekel, da moraš v življenju vedno izbrati cesto, ki gre naprej, tudi če je napačna, te nekam pripelje; spremenila me je babuška v etnografskem muzeju v Rusiji, ki se je pri 75 letih ponovno zaljubila in mi navdušena povedala svojo zgodbo. Kot zadnje in ne tako nepomembno je življenje $\mathrm{v}$ tujini spremenilo način mojega govora, mojega izražanja.

\section{Kaj ti zdaj pomeni Argentina?}

Trenutno je Buenos Aires kraj, kjer vse povezujem s plesom. Tečaji mi zavzamejo precej časa, pripravljamo dva plesna nastopa $\mathrm{v}$ decembru s skupino Alma. To je skupina, ki povezuje plesalce na vozičkih. Mesto je en sam teater. Ogromno gledaliških predstav, koncertov, festivalov, je prava meka za umetnike. Tukaj je moj trenutni dom. 